\title{
PENGEMBANGAN MEDIA PEMBELAJARAN MATEMATIKA BERBASIS GEOGEBRA UNTUK MENINGKATKAN KEMAMPUAN PEMAHAMAN KONSEP SISWA
}

\author{
Etty Ristiana Anggraeni ${ }^{1}$, Ma'rufi $^{2}$, Suaedi ${ }^{3}$ \\ Universitas Cokroaminoto Palopo ${ }^{1,2,3}$ \\ Email: ettyristianaanggraeni@gmail.com ${ }^{1}$, marufi.ilyas@gmail.com² ${ }^{2}$, \\ suadif@gmail.com ${ }^{3}$
}

\begin{abstract}
Abstrak. Penelitian ini bertujuan untuk mengetahui proses pengembangan media pembelajaran berbasis GeoGebra untuk meningkatkan kemampuan pemahaman konsep siswa yang memenuhi kriteria valid, praktis dan efektif. Penelitian ini dilaksanakan di SMP Datok Sulaiman Palopo. Penelitian ini merupakan jenis penelitian pengembangan Research \& Development (R\&D) yang dikembangkan dengan menggunakan model 4D (Define, Design, Development, Dissemination). Subyek uji coba penelitian ditentukan dengan metode purposive sampling sebanyak 33 orang. Hasil penelitian menunjukkan bahwa proses pengembangan media pembelajaran berbasis GeoGebra melalui 4 tahap yaitu tahap pendefinisian, perancangan, pengembangan dan penyebaran. Hasil pengembangan berupa media pembelajaran berbasis GeoGebra untuk meningkatkan kemampuan pemahaman konsep siswa yang memenuhi kriteria valid, praktis dan efektif. Hal ini ditunjukkan dengan hasil validasi ahli media 3,53 dan ahli materi 3,47 berada pada kategori tinggi dengan tingkat kevalidan valid. Hasil observasi keterlaksanaan penggunaan media sebesar 3,69 dengan rata-rata 89\% media pembelajaran dapat dilaksanakan masuk kategori tinggi dengan tingkat kepraktisan praktis. Hasil tes penguasaan materi $81,81 \%$ siswa mencapai ketuntasan belajar dengan kemampuan pemahaman konsep $71,47 \%$ berada pada kategori cukup dengan nilai gain rata-rata 0,6 berada pada kategori sedang dan 94,27 siswa merespon positif sehingga memenuhi kriteria efektif.
\end{abstract}

\section{Keywords: $\quad$ Media Pembelajaran, GeoGebra, Pemahaman Konsep}

\begin{abstract}
This study aims to determine the process of developing GeoGebra-based learning media to improve students' conceptual understanding skills that meet valid, practical and effective criteria. This research was conducted at SMP Datok Sulaiman Palopo. This research is a Research \& Development (R\&D) type of research developed using the 4D model (Define, Design, Development, Dissemination). The research trial subjects were determined by purposive sampling method as many as 33 people. The results showed that the process of developing GeoGebra-based learning media went through 4 stages, namely defining, designing, developing and distributing. The result of the development is in the form of GeoGebra-based learning media to improve students' conceptual understanding skills that meet valid, practical and effective criteria. This is indicated by the results of the validation of the media expert 3.53 and the material expert 3.47 in the high category with a validity level. The results of observations of the implementation of the use of media were 3.69 with an average of $89 \%$ of learning media which could be implemented in the high category with a level of practical practicality. The results of the mastery test of the material $81.81 \%$ of students achieved mastery learning with the ability to understand concepts $71.47 \%$ were in the sufficient category with an average gain value of 0.6 in the medium category and 94.27 students responded positively so that they met the effective criteria.
\end{abstract}

\section{Keywords: $\quad$ Learning Media, GeoGebra, Concept Understanding}

\section{A. Pendahuluan}

Pendidikan merupakan salah satu tolok ukur kemajuan sebuah negara. Negara maju mempunyai pendidikan yang baik dan mampu mencetak sumber daya manusia yang berkualitas. Seiring dengan perkembangan zaman revolusi 4.0, cara kerja manusia berubah menjadi otomatisasi atau digitalisasi. Hal ini dipengaruhi oleh perkembangan internet dan teknologi digital yang sangat masif (Bayu, Zulkifli, dan Syaputra, 2018). Salah satu pengaruhnya di dunia pendidikan yaitu pada aktivitas sekolah, dimana informasi dan 
pengetahuan baru cepat menyebar dan mudah diakses oleh siapa saja yang membutuhkannya. Hal ini menjadi tantangan berat bagi guru, dimana peran guru sebagai penyedia ilmu telah bergeser. Kehadiran guru di dalam kelas tidak hanya menyampaikan pengetahuan, tetapi mengajarkan sikap dan ketrampilan agar peserta didik mempunyai kecerdasan yang lebih unggul daripada kecerdasan mesin dan bersikap bijak dalam menggunakan mesin demi kemaslahatan.

Salah satu ilmu yang dibutuhkan untuk menghadapi era revolusi industri 4.0 dan meningkatkan penguasaan ilmu pengetahuan dan teknologi adalah matematika. Matematika adalah ilmu universal yang mendasari perkembangan teknologi modern dan mempunyai peran penting dalam berbagai disiplin ilmu dan mengembangkan daya pikir manusia (Marufi, Pasandaran, dan Yogi, 2018). Untuk itu diperlukan pemahaman konsep yang bagus dalam belajar matematika. Karena kemampuan pemahaman konsep merupakan kunci keberhasilan untuk mewujudkan lima standar yang ditetapkan National Council of Teachers of Mathematics (NTCM) terdapat pada kurikulum matematika tingkat Sekolah Menengah Pertama (SMP). Lima standar tersebut meliputi kemampuan pemecahan masalah, penalaran dan pembuktian, komunikasi, koneksi, dan representasi yang merupakan cara penting untuk memperoleh dan menggunakan pengetahuan (NCTM, 2000).

Pemahaman konsep dibutuhkan untuk menyelesaikan masalah dalam pembelajaran matematika. Untuk menghadapi perubahan zaman, pemahaman konsep sangat dibutuhkan untuk mengembangkan kemampuan berpikir kritis dan sistematis, kemampuan penalaran dan mengembangkan sikap obyektif dan terbuka dalam menghadapi permasalahan kehidupan sehari-hari. Pemahaman konsep dalam pembelajaran matematika menjadi hal yang penting agar peserta didik tidak mengalami kesulitan dalam belajar (Hadiyanti, 2012).

Salah satu upaya untuk meningkatkan kemampuan pemahaman konsep adalah menggunakan media pembelajaran dalam mengajarkan konsep matematika kepada peserta didik. Media pembelajaran merupakan sarana yang membantu proses pembelajaran. Media pembelajaran mempercepat kegiatan pembelajaran menjadi efektif dan efisien dalam suasana yang kondusif, sehingga dapat membuat pemahaman peserta didik lebih cepat (Wibawanto, 2017). Untuk menghadapi era revolusi industri 4.0, banyak orang memanfaatkan media pembelajaran interaktif berbantuan komputer.

Media pembelajaran interaktif merupakan media pembelajaran yang memungkinkan terjadinya komunikasi dua arah atau lebih dari komponen-komponen komunikasi. Media pembelajaran interaktif didisain agar pengguna merespon untuk melakukan suatu aktivitas, sehingga media pembelajaran interaktif tidak seperti media pasif semisal media cetak yang tidak bisa melakukan kendali terhadap penggunanya. Dalam hal ini, pengguna (peserta didik) berinteraksi dengan media pembelajaran yang berisi materi yang dipelajari. Media pembelajaran ini dilengkapi dengan alat pengontrol yang dapat dioperasikan oleh pengguna, sehingga pengguna dapat memilih apa yang dikehendaki untuk proses selanjutnya (Prastowo, 2011).

Salah satu media pembelajaran interaktif yang dapat digunakan untuk meningkatkan kemampuan pemahaman konsep adalah media pembelajaran berbasis GeoGebra. GeoGebra merupakan laman (website) penyedia aplikasi matematika yang dapat diakses melalui geogebra.org. Melalui laman GeoGebra dapat diunduh software atau aplikasi GeoGebra yang dapat diakses secara offline. GeoGebra merupakan perangkat lunak open source yang dapat digunakan dan digandakan secara gratis. GeoGebra dapat diakses di segala jenis komputer seperti PC, tablet dan berbagai sistem komputer seperti Windows, Mac OS, Linux dan sebagainya. GeoGebra dikembangkan oleh Markus Hohenwarter, matematikawan Austria dan profesor di Universitas Johannes Kepler (JKU) Linz mulai tahun 2001. Markus Hohenwarter adalah ketua Lembaga Pendidikan Matematika yang mengembangkan perangkat lunak pendidikan matematika GeoGebra. Markus Hohenwarter telah memenangkan berbagai 
penghargaan software di Eropa dan Amerika Serikat. Penelitiannya berfokus pada penggunaan teknologi dalam pendidikan matematika (Syahbana, 2016).

GeoGebra merupakan perangkat lunak matematika yang dinamis, bebas, dan multiplatform. GeoGebra menggabungkan geometri, aljabar, tabel, grafik, statistik dan kalkulus dalam satu paket yang mudah dan bisa digunakan untuk semua jenjang pendidikan (Hidayat dan Tamimuddin, 2015). GeoGebra dapat menghasilkan aplikasi matematika yang interaktif melalui laman GeoGebra.org. Sehingga laman Geogebra.org dapat dijadikan salah satu alternatif penyebarluasan media pembelajaran berbasis GeoGebra Selain itu pada laman GeoGebra terdapat fitur GeoGebra Classroom yang dapat digunakan untuk menampilkan aktivitas-aktivitas yang dibuat melalui aplikasi GeoGebra, sehingga bisa diakses peserta didik tanpa harus menginstal aplikasi GeoGebra di komputernya. Melalui GeoGebra Classroom dapat diberikan tugas-tugas maupun soal-soal kepada peserta didik.

Selain GeoGebra Classroom terdapat juga GeoGebra Group yang dapat digunakan untuk membuat kelas pembelajaran, dimana pendidik dan peserta didik saling berinteraksi satu sama lain. Dalam GeoGebra Group guru bisa memberikan pengumuman, tugas, mengupload materi, mengupload aktivitas yang dibuat dengan menggunakan software GeoGebra dan latihan soal. Guru bisa memantau keterlaksanaan penggunaan media pembelajaran oleh siswa dalam mengakses tugas-tugas yang diberikan. Jadi GeoGebra Group dapat dikatakan sebagai halaman LMS (Learning Management System) atau sistem manajemen pembelajaran. Melalui sistem manajemen pembelajaran yang ada di dalam GeoGebra Group, siswa dapat melihat kemajuan proses belajarnya.

Melalui media pembelajaran berbasis GeoGebra, diyakini dapat meningkatkan kemampuan pemahaman konsep. GeoGebra memiliki kemampuan menyelesaikan masalah aritmatika, aljabar, statistik, dan geometri. Menurut Mahmudi (Agung, Ma'rufi, \& Ilyas, 2019) GeoGebra dapat dimanfaatkan sebagai media pembelajaran matematika khususnya geometri untuk mendemonstrasikan atau memvisualisasikan konsep-konsep geometri serta sebagai alat bantu untuk mengkonstruksi konsep-konsep geometri. Selain itu, GeoGebra mampu memvisualisasikan obyek geometri dan dapat menggambarkan masalah geometri, sehingga akan lebih mudah dalam memahami konsep yang diperlukan. Dengan adanya software GeoGebra ini, maka dapat dipakai sebagai media praktek guru dalam pembelajaran di kelas. Hal ini dikuatkan oleh hasil penelitian terdahulu yang dilakukan Purwanti, Pratiwi, \& Rinaldi, (2016) bahwa pembelajaran berbantuan GeoGebra berpengaruh terhadap kemampuan pemahaman konsep matematika siswa dengan nilai statistik sebeesar 8,871 ( $p>4,001)$. Untuk menunjang kemampuan pemahaman konsep diperlukan kemampuan proses berpikir yang dilakukan siswa secara aktif untuk mengembangkan dan membangun pengetahuan berdasarkan pengalamannya. Adapun indikator kemampuan pemahaman konsep yang digunakan pada penelitian ini adalah kemampuan 1) menyatakan ulang sebuah konsep, Mengklasifikasi obyekobyek menurut sifat-sifat tertentu (sesuai dengan konsepnya); 3) Menggunakan, memanfaatkan, dan memilih prosedur atau operasi tertentu; 4) Mengaplikasikan konsep atau algoritma pemecahan masalah.

Berdasarkan latar belakang di atas, peneliti tertarik untuk mengadakan penelitian pengembangan media pembelajaran berbasis GeoGebra untuk meningkatkan kemampuan pemahaman konsep siswa. 


\section{B. Metode Penelitian}

Penelitian ini dilakukan pada masa pandemi covid-19. Pada masa ini kemdikbud mengeluarkan edaran tentang pembatasan pelaksanaan proses belajar mengajar. Kurikulum yang digunakan adalah kurikulum darurat dengan kompetensi dasar yang diajarkan hanya kompetensi dasar esensial dengan alokasi waktu pembelajaran dikurangi. Pada masa pandemi ini pemerintah menghimbau untuk melaksanakan kegiatan belajar dari rumah dengan cara daring (online). Sehingga untuk mencapai target kompetensi pada kurikulum darurat ini diperlukan media pembelajaran yang tepat untuk keberlangsungan proses belajar mengajar.

Maka dari itu peneliti melakukan penelitian pengembangan media pembelajaran yang dapat digunakan selama proses pembelajaran jarak jauh. Jenis penelitian ini termasuk penelitian pengembangan atau Research and Development (R\&D) merupakan penelitian yang menghasilkan suatu produk. Metode penelitian dan pengembangan adalah metode penelitian yang digunakan untuk menghasilkan suatu produk tertentu serta menguji keefektifan produk tersebut (Sugiyono, 2012). Penelitian dilaksanakan di SMP Datok Sulaiman bagian putri yang beralamat di Jalan Puang H. Daud No 5 Kelurahan Tompotikka Kecamatan Wara Kota Palopo. Uji coba penelitian dilaksanakan secara online dengan subyek uji coba penelitian sebanyak 33 orang siswa kelas VII.

Model pengembangan dalam penelitian ini adalah model 4D. Model ini terdiri dari 4 tahap pengembangan, yaitu define (pendefinisian), design (perancangan), develop (pengembangan) dan disseminate (penyebaran). Model ini disusun secara terprogram dengan urutan-urutan kegiatan yang sistematis dalam upaya memecahkan masalah pembelajaran, khususnya masalah ketersediaan sumber belajar yang sesuai dengan kebutuhan siswa (Rochmad, 2012). Tahapan penelitian pengembangan dapat digambarkan sebagai berikut:

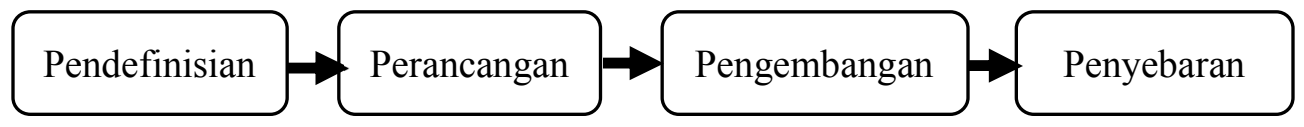

Gambar 1. Tahapan Pengembangan 4D

Instrumen dalam pengumpulan data ini meliputi lembar validasi, Rencana Pelaksanaan Pembelajaran (RPP), angket keterlaksanaan penggunaan media pembelajaran, angket respon siswa, dan hasil tes kemampuan pemahaman konsep materi segiempat dan segitiga. Seluruh instrumen pengumpulan data sebelum digunakan, terlebih dahulu divalidasi oleh para ahli, yaitu dua orang dosen pendidikan matematika untuk mengetahui validitas instrumen-instrumen tersebut. Lembar validasi terdiri dari lembar validasi media pembelajaran, lembar validasi materi pada media pembelajaran, lembar validasi RPP, lembar validasi angket keterlaksanaan penggunaan media pembelajaran, lembar validasi angket respon siswa dan lembar validasi kisikisi dan tes pemahaman konsep. Validasi dilakukan oleh para ahli media dan ahli materi yang tergabung dalam Pusat Studi Pendidikan, Pembelajaran dan Lesson Study Universitas Cokroaminoto Palopo. Hasil validasi media pembelajaran dari ahli media dan ahli materi digunakan untuk memperoleh data kevalidan media pembelajaran hasil pengembangan. Selanjutnya hasil validasi di rata-rata kemudian hasilnya disesuaikan dengan kriteria kevalidan seperti pada tabel berikut:

Tabel 1. Kriteria Kevalidan

\begin{tabular}{lll}
\hline Interval & Kategori & Tingkat kevalidan \\
\hline $1 \leq \mathrm{V}_{a}<2$ & Rendah & Tidak valid \\
$2 \leq \mathrm{V}_{a}<3$ & Sedang & Cukup valid \\
$3 \leq \mathrm{V} a \leq 4$ & Tinggi & Valid \\
\hline
\end{tabular}

Diadaptasi dari Parta (2009)

Keterangan: 
$\mathrm{V} a$ adalah rata-rata keseluruhan skor kevalidan

Angket keterlaksanaan penggunaan media pembelajaran diberikan setiap kali pertemuan. Hal ini bertujuan untuk mengetahui sejauh mana media pembelajaran hasil pengembangan dapat digunakan oleh pengguna. Hasil data angket keterlaksanaan penggunaan media pembelajaran digunakan untuk memperoleh data kepraktisan media pembelajaran hasil pengembangan. Selanjutnya hasilnya di rata-rata kemudian disesuaikan dengan kriteria kepraktisan media pembelajaran seperti pada tabel berikut:

Tabel 2. Kriteria Penilaian Keterlaksanaan Penggunaan Media Pembelajaran

\begin{tabular}{lll}
\hline Interval & Kategori & Tingkat kepraktisan \\
\hline $0 \% \leq k<50 \%$ & Rendah & Tidak praktis \\
$k=50 \%$ & Sedang & Cukup praktis \\
$50 \%<k \leq 100 \%$ & Tinggi & Praktis \\
\hline
\end{tabular}

Diadaptasi dari Fatgianto (2018)

Keterangan:

$k=$ rata-rata keseluruhan skor angket keterlaksanaan penggunaan media pembelajaran

Angket respon siswa diberikan pada pertemuan terakhir setelah mengerjakan postes. Melalui pemberian angket respon siswa dan tes penguasaan materi dapat diperoleh data yang menunjukkan keefektifan media pembelajaran. Hasil tes penguasaan materi dihitung dengan menggunakan perhitungan sebagai berikut:

Persentase ketuntasan belajar $(k b)=\frac{\text { Jumlah Skor Perolehan }}{\text { Jumlah Skor Keseluruhan }} \times 100 \%$

Selanjutnya hasi perhitungan mengacu pada kriteria sebagai berikut:

Tabel 3. Tingkat Ketuntasan Belajar

\begin{tabular}{cc}
\hline Interval & Tingkat ketuntasan belajar \\
\hline $0 \leq \mathrm{kb}<40$ & Sangat rendah \\
$40 \leq \mathrm{kb}<70$ & Rendah \\
$70 \leq \mathrm{kb}<80$ & Sedang \\
$80 \leq \mathrm{kb}<90$ & Tinggi \\
$90 \leq \mathrm{kb} \leq 100$ & Sangat tinggi \\
\hline
\end{tabular}

Diadaptasi dari Hobri (2010)

Untuk menganalisis kemampuan pemahaman konsep digunakan pedoman penskoran dan kriteria tingkat pemahaman konsep sebagai berikut:

\begin{tabular}{llll}
\hline Jawaban & Alasan & Skor & Kriteria \\
\hline Benar & Benar & 1 & Paham \\
Benar & Salah & 0 & Kurang Paham \\
Salah & Benar & 0 & Kurang Paham \\
Salah & Salah & 0 & Tidak Paham \\
\hline
\end{tabular}

Kemudian untuk mengetahui persentase pemahaman konsep siswa setiap indikator dihitung dengan persamaan berikut:

Persentase pemahaman konsep siswa $(X)=\frac{\text { Jumlah siswa paham } \text { konsep }}{\text { Jumlah Skor Keseluruhan }} \times 100 \%$

Untuk mengetahui besarnya peningkatan kemampuan pemahaman konsep dengan menghitung n-gain. Perhitungan data analisis n-gain menggunakan gain ternormalisasi yang dikembangkan oleh Meltzer menggunakan rumus: 


$$
g=\frac{\text { Nilai Posttes }- \text { Nilai Pretes }}{\text { Nilai Maksimum }- \text { Nilai Pretes }}
$$

Kemudian hasil perhitungan disesuaikan dengan kriteria skor gain sesuai tabel berikut:

Tabel 4. Kriteria Skor Gain Ternormalisasi

\begin{tabular}{ll}
\hline Skor Gain & Interpretasi \\
\hline $0,7<\mathrm{g} \leq 1,0$ & Tinggi \\
$0,3<\mathrm{g} \leq \mathbf{0 , 7}$ & Sedang \\
$\mathrm{g} \leq 0,3$ & Rendah
\end{tabular}

Diadaptasi dari Hobri (2010)

Hasil angket respon siswa dalam pembelajaran ditentukan dengan kriteria sebagai berikut.

[1] Jika $\bar{S}_{l} \geq 0,5$, maka dikatakan subjek ke-i memberi respon positif.

[2] Jika $\bar{S}_{l}<0,5$, maka dikatakan subjek ke-i memberi respon negatif.

Sedangkan respon kelas, ditentukan dengan kriteria sebagai berikut.

[1] Jika $\bar{S} \geq 0,5$ maka dikatakan subjek ke-i memberi respon positif.

[2] Jika $\bar{S}<0,5$ maka dikatakan subjek ke-i memberi respon negatif.

Jadi media pembelajaran hasil pengembangan ini dikatakan menarik apabila siswa memberikan respon positif. Target dari media pembelajaran berbasis GeoGebra yang dikembangkan adalah berkriteria menarik ditunjukan dengan minimal $75 \%$ respon positif yang diberikan oleh responden. Berdasarkan dua indikator atas, media pembelajaran hasil pengembangan ini dikatakan efektif apabila secara klasikal hasil tes penguasaan materi telah dinyatakan tuntas dan siswa memberikan respon positif.

\section{Hasil Penelitian dan Pembahasan}

Hasil pengembangan media pembelajaran melalui 4 tahapan yaitu:

\section{Define (Pendeifinisian)}

Pada tahap ini dilakukan analisis awal-akhir, analisis pembelajar, analisis tugas, analisis konsep dan perumusan tujuan pembelajaran. Analisis awal-akhir menelaah kurikulum yang digunakan buku siswa yang dipakai, dan teori yang relevan sehingga diperoleh deskripsi media pembelajaran yang relevan untuk dikembangkan untuk mengatasi permasalahan yang dihadapi siswa. Berdasarkan pengamatan peneliti, pembelajaran matematika di SMP Datok Sulaiman menggunakan kurikulum 2013 yang disederhanakan menjadi kurikulum darurat. Buku siswa yang digunakan buku matematika edisi revisi 2018. Analisis pembelajar dilakukan dengan mengidentifikasi relevansi karakteristik siswa terhadap pengembangan media pembelajaran. Siswa SMP Datok Sulaiman berasal dari berbagai daerah yang tersebar di pulau Sulawesi dan memiliki rasa Ketertarikan terhadap teknologi komputer dan internet sehingga peneliti dapat mengembangkan media pembelajaran yang menggunakan komputer dan internet. Analisis tugas dan analisis konsep dilakukan dengan mengidentifikasi indikator yang ada pada kompetensi dasar yang dipelajari. Setelah teridentifikasi disusunlah tujuan pembelajaran yang akan dicapai siswa.

\section{Design (Tahap Perancangan)}

Pada tahap ini disiapkan prototipe perangkat pembelajaran yaitu mengkonstruksi tes, memilih media, memilih format, dan melakukan design awal. Tes yang digunakan pada penelitian ini adalah tes pemahaman konsep berbentuk pilihan ganda sebanyak 12 nomor. Media yang dipilih adalah media pembelajaran menggunakan software GeoGebra dengan format yang menarik yang terdiri dari 33 frame dengan desain awal seperti pada gambar flowchart berikut: 


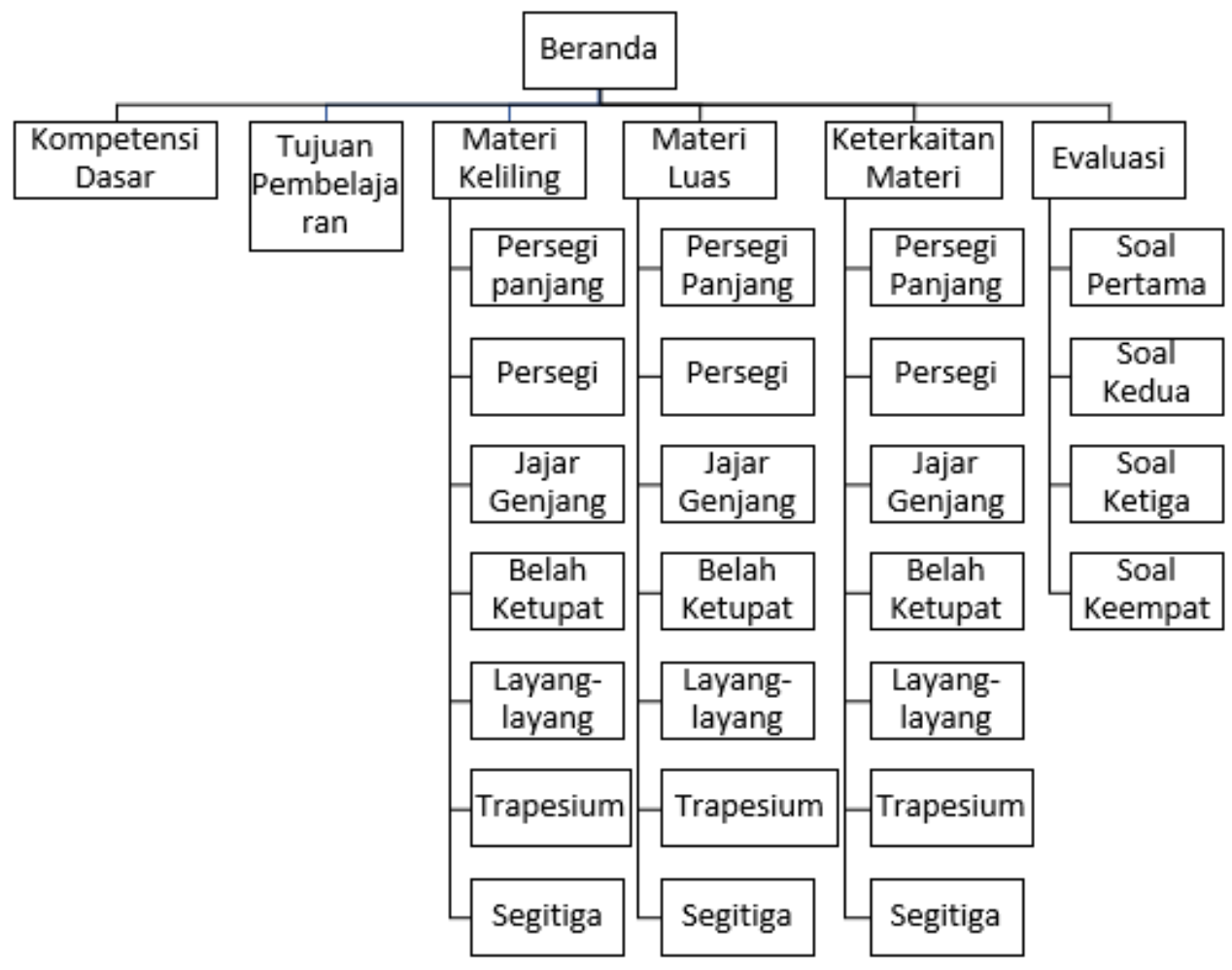

Gambar 2. Rancangan Flowchart Media Pembelajaran Berbasis GeoGebra

\section{Development (Tahap Pengembangan)}

Pada tahap pengembangan produk dikembangkan sesuai desain awal. Beberapa tampilan frame pada media pembelajaran tampak sebagai berikut:
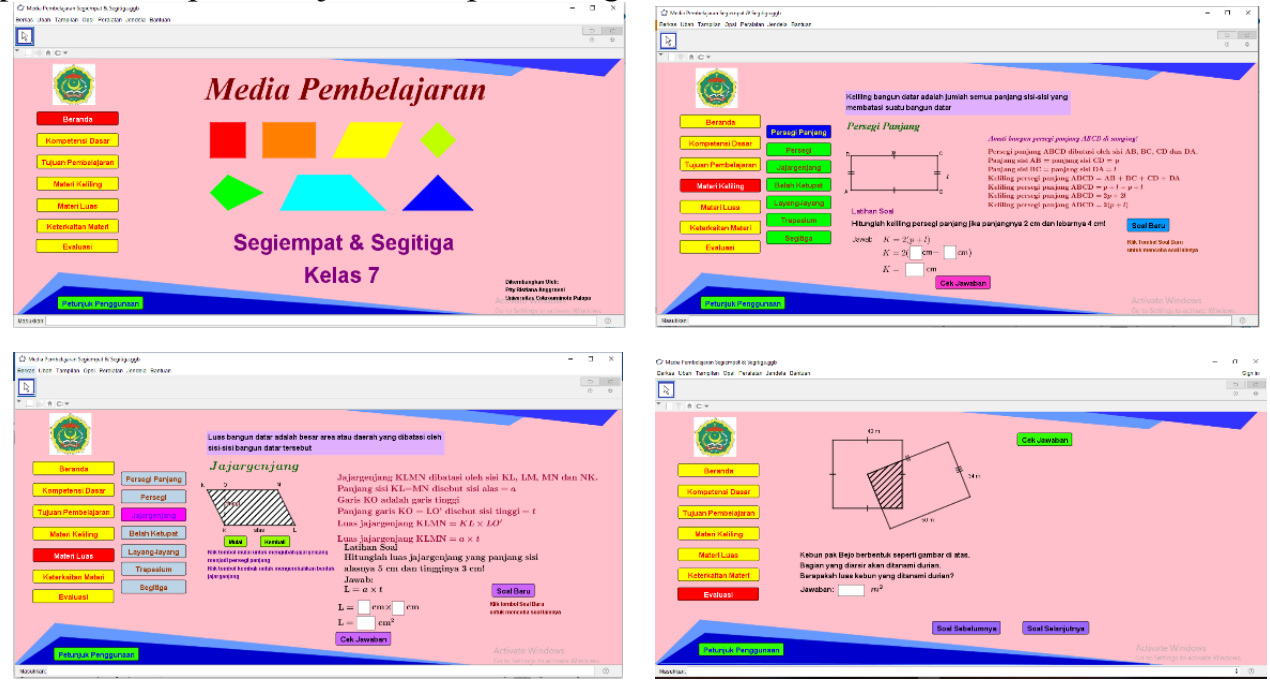

Gambar 3. Tampilan frame media pembelajaran

Setelah produk jadi, dilakukan uji validitas yang dilakukan oleh ahli media dan ahli materi. Hasil kelayakan produk dari ahli media dapat dilihat pada tabel berikut:

Tabel 5. Hasil Kelayakan Produk Dari Ahli Media

\begin{tabular}{lllcc}
\hline \multirow{2}{*}{ No } & \multirow{2}{*}{ Aspek Penilaian } & \multicolumn{3}{c}{ Penilaian } \\
\cline { 2 - 5 } & & Validator I & Validator II & Rata-rata \\
\hline 1 & Lay Out (Tampilan Media) & 13 & 53 & 3,38 \\
\hline
\end{tabular}




\begin{tabular}{lllll}
\hline 2 & Isi & 33 & 57 & 3,50 \\
3 & Bahasa yang Digunakan & 50 & ) 0 & 3,75 \\
4 & Waktu yang Disediakan & 50 & ) 0 & 3,75 \\
5 & Metode Sajian yang Digunakan & 50 & ) 0 & 3,25 \\
\hline & Rata-rata & & 3,53 \\
\hline
\end{tabular}

Sumber: Data Primer yang diolah peneliti, 2020

Berdasarkan tabel hasil validasi kelayakan produk dari ahli media menunjukkan rata-rata 3,53 termasuk dalam kategori tinggi dengan tingkat kevalidan valid.

Sedangkan hasil validasi kelayakan produk dari ahli materi dapat dilihat pada tabel berikut:

Tabel 6. Hasil Kelayakan Produk Dari Ahli Materi

\begin{tabular}{llccc}
\hline \multirow{2}{*}{ No } & \multirow{2}{*}{ Aspek Penilaian } & \multicolumn{3}{c}{ Penilaian } \\
\cline { 2 - 4 } & Isi & Validator I & Validator II & Rata-rata \\
\hline 1 & Bahasa, Tulisan dan Tampilan & 3,67 & 3,71 & 3,57 \\
3 & Manfaat Media Pembelajaran & 3,00 & 3,00 & 3,84 \\
\hline \multicolumn{2}{c}{ Rata-rata } & & 3,00 \\
\hline
\end{tabular}

Sumber: Data Primer yang diolah peneliti, 2020

Berdasarkan tabel hasil validasi kelayakan produk dari ahli materi menunjukkan rata-rata 3,47 termasuk dalam kategori tinggi dengan tingkat kevalidan valid. Sehingga media pembelajaran matematika berbasis GeoGebra materi segiempat dan segitiga yang dikembangkan peneliti dapat diuji cobakan.

Hasil analisis kepraktisan media pembelajaran melalui angket keterlaksanaan penggunakan media pembelajaran ditunjukkan pada tabel berikut:

Tabel 7. Hasil Angket Keterlaksanaan Media Pembelajaran Pada Ujia Coba II

\begin{tabular}{|c|c|c|c|c|c|c|c|c|c|c|}
\hline \multirow[b]{2}{*}{ No } & \multirow{2}{*}{ Aspek Penilaian } & \multicolumn{6}{|c|}{ Pertemuan } & \multirow{2}{*}{$\begin{array}{l}\text { Rata- } \\
\text { rata }\end{array}$} & \multirow{2}{*}{$\begin{array}{l}\text { Kate } \\
\text { gori }\end{array}$} & \multirow{2}{*}{$\begin{array}{l}\text { Tingkat } \\
\text { Keprak } \\
\text { tisan }\end{array}$} \\
\hline & & 1 & 2 & 3 & 4 & 5 & 6 & & & \\
\hline 1 & $\begin{array}{l}\text { Kemudahan } \\
\text { menggunakan } \\
\text { menu-menu dalam } \\
\text { media }\end{array}$ & 92,4 & 87,3 & 89,5 & 93,9 & 87,9 & 100 & 91,8 & Tinggi & Praktis \\
\hline 2 & Keterbacaan & 90,9 & 88,3 & 90 & 91,3 & 100 & 100 & 93,4 & Tinggi & Praktis \\
\hline 3 & $\begin{array}{l}\text { Keterlaksanaan } \\
\text { aktivitas penalaran } \\
\text { spasial }\end{array}$ & & 79,9 & 82,9 & & 82,6 & & 81,8 & Tinggi & Praktis \\
\hline & Rata-rata & 91,7 & 85,2 & 87,5 & 92,6 & 90,2 & 100 & 89 & Tinggi & Praktis \\
\hline
\end{tabular}

Sumber: Data Pribadi Peneliti, (2021)

Berdasarkan hasil pemberian angket keterlaksanaan penggunaan media pembelajaran pada tabel 7 menunjukkan bahwa rata-rata keterlaksanaan penggunaan media pembelajaran pada saat uji coba adalah $89 \%$ termasuk dalam kategori tinggi dengan tingkat kepraktisan praktis.

Hasil tes penguasaan materi disajikan pada tabel berikut:

Tabel 8. Hasil Tes Penguasaan Materi

Banyak Siswa

res 33 


\begin{tabular}{lc} 
Nilai Maksimal & 100 \\
Nilai Tertinggi & 100 \\
Nilai Terendah & 33,33 \\
Varian & 197,42 \\
Median & 75 \\
Range & 66,67 \\
Rata-rata Nilai & 77,53 \\
Standar Deviasi & 14,05 \\
Tingkat Ketuntansan Belajar Sangat Tinggi & 7 \\
Tingkat Ketuntansan Belajar Tinggi & 9 \\
Tingkat Ketuntansan Belajar Sedang & 11 \\
Tingkat Ketuntansan Belajar Rendah & 5 \\
Tingkat Ketuntansan Belajar Sangat Rendah & 1 \\
\hline Sunar: Data Prim &
\end{tabular}

Sumber: Data Primer yang diolah peneliti, 2020

Dari data tersebut di atas terdapat 27 dari 33 siswa $(81,81 \%)$ yang memiliki tingkat ketuntasan minimal sedang dan 6 dari 7 siswa $(18,18 \%)$ yang memiliki tingkat ketuntasan rendah dan sangat rendah. Berdasarkan pedoman analisis data tabel 3 bahwa pembelajaran menggunakan media pembelajaran hasil pengembangan dikatakan tuntas apabila minimal $80 \%$ siswa yang mengikuti pembelajaran mampu memiliki tingkat ketuntasan belajar, maka dapat disimpulkan bahwa tercapai ketuntasan belajar secara klasikal.

Data hasil tes pemahaman konsep disajikan pada tabel berikut:

Tabel 9. Hasil Tes Pemahaman Konsep

\begin{tabular}{|c|c|c|c|c|c|}
\hline \multirow{2}{*}{ No } & \multirow{2}{*}{ Indikator } & \multicolumn{4}{|c|}{ Persentase Pemahaman Konsep Siswa } \\
\hline & & Pretes & Kategori & Postes & Kategori \\
\hline 1 & $\begin{array}{l}\text { Menyatakan ulang sebuah } \\
\text { konsep. }\end{array}$ & 40,4 & Kurang & 74,75 & Cukup \\
\hline 2 & $\begin{array}{l}\text { Mengklasifikasi obyek-obyek } \\
\text { menurut sifat-sifat tertentu } \\
\text { (sesuai dengan konsepnya) }\end{array}$ & 13,13 & Sangat Kurang & 71,72 & Cukup \\
\hline 3 & $\begin{array}{l}\text { Menggunakan, memanfaatkan, } \\
\text { dan memilih prosedur atau } \\
\text { operasi tertentu. }\end{array}$ & 22,22 & Sangat Kurang & 69,7 & Cukup \\
\hline 4 & $\begin{array}{l}\text { Mengaplikasikan konsep atau } \\
\text { algoritma pemecahan masalah. }\end{array}$ & 30,3 & Sangat Kurang & 69,7 & Cukup \\
\hline & Rata-rata & 26,51 & Sangat Kurang & 71,47 & Cukup \\
\hline
\end{tabular}

Sumber: Data Primer yang diolah peneliti, 2021

Secara umum rata-rata kemampuan pemahaman konsep siswa saat pretes mencapai $26,51 \%$ berada pada kategori sangat kurang. Sedangkan pada saat postes rata-rata kemampuan pemahaman konsep siswa mencapai $71,47 \%$ berada pada kategori cukup. Dalam hal ini terdapat peningkatan kemampuan pemahaman konsep siswa sebesar $34,89 \%$ dari $26,51 \%$ menjadi $71,47 \%$. Untuk mengetahui besarnya peningkatan kemampuan pemahaman konsep yang terjadi pada siswa dilakukan analisis data dengan mencari nilai gain melalui perbandingan hasil pretes dengan postes tiap siswa.

Tabel 10. Peningkatan Kemampuan Pemahaman Konsep

\begin{tabular}{llcccc}
\hline \multirow{2}{*}{ No } & \multirow{2}{*}{ Responden } & \multicolumn{4}{c}{ Banyaknya Soal dipahami } \\
\cline { 3 - 6 } & & Pretes & Postes & Skor Gain & Interpretasi \\
\hline 1 & R1 & 3 & 7 & 0,4 & Sedang \\
2 & R2 & 8 & 11 & 0,8 & Tinggi \\
3 & R3 & 1 & 8 & 0,6 & Sedang \\
4 & R4 & 5 & 9 & 0,6 & Sedang \\
5 & R5 & 3 & & Sedang \\
\hline
\end{tabular}




\begin{tabular}{|c|c|c|c|c|c|}
\hline \multirow{2}{*}{ No } & \multirow{2}{*}{ Responden } & \multicolumn{4}{|c|}{ Banyaknya Soal dipahami } \\
\hline & & Pretes & Postes & Skor Gain & Interpretasi \\
\hline 6 & R6 & 5 & 7 & 0,4 & Tinggi \\
\hline 7 & R7 & 4 & 12 & 1,0 & Sedang \\
\hline 8 & R8 & 1 & 9 & 0,6 & Sedang \\
\hline 9 & R9 & 1 & 9 & 0,7 & Sedang \\
\hline 10 & $\mathrm{R} 10$ & 5 & 9 & 0,7 & Sedang \\
\hline 11 & R11 & 4 & 9 & 0,1 & Sedang \\
\hline 12 & $\mathrm{R} 12$ & 1 & $\begin{array}{l}9 \\
8\end{array}$ & 0,0 & Sedang \\
\hline 13 & $\mathrm{R} 13$ & 1 & 8 & 0,5 & Sedang \\
\hline 14 & R14 & 3 & 8 & 0,6 & Sedang \\
\hline 15 & $\mathrm{R} 15$ & 3 & 8 & 0,6 & Sedang \\
\hline 16 & R16 & 2 & 9 & 0,7 & Sedang \\
\hline 17 & $\mathrm{R} 17$ & 4 & 8 & 0,6 & Sedang \\
\hline 18 & $\mathrm{R} 18$ & $\begin{array}{l}4 \\
5\end{array}$ & 8 & 0,6 & Tinggi \\
\hline 19 & R19 & $\begin{array}{l}5 \\
4\end{array}$ & 7 & 0,4 & Sedang \\
\hline 20 & $\mathrm{R} 20$ & 4 & 11 & 0,9 & Rendah \\
\hline 21 & $\mathrm{R} 21$ & 1 & 7 & 0,4 & Sedang \\
\hline 22 & R22 & 3 & 4 & & Sedang \\
\hline 23 & $\mathrm{R} 23$ & 10 & $\begin{array}{l}4 \\
0\end{array}$ & 0,3 & Sedang \\
\hline 24 & $\mathrm{R} 24$ & 2 & 9 & 0,7 & Rendah \\
\hline 25 & $\mathrm{R} 25$ & 3 & 11 & 0,5 & Tinggi \\
\hline 26 & R26 & 2 & 9 & 0,7 & Sedang \\
\hline 27 & $\mathrm{R} 27$ & 2 & 6 & 0,3 & Sedang \\
\hline 28 & $\mathrm{R} 28$ & 4 & 10 & 0,8 & Rendah \\
\hline 29 & R29 & 6 & 7 & 0,5 & Tinggi \\
\hline 30 & $\mathrm{R} 30$ & $\begin{array}{l}0 \\
3\end{array}$ & 9 & 0,6 & Sedang \\
\hline 31 & R31 & $\begin{array}{l}3 \\
1\end{array}$ & 8 & 0,3 & Tinggi \\
\hline 32 & $\mathrm{R} 32$ & 1 & 11 & 0,9 & Sedang \\
\hline \multirow[t]{5}{*}{33} & $\mathrm{R} 33$ & 1 & 9 & 0,7 & Sedang \\
\hline & & 1 & 10 & 0,8 & \\
\hline & & 3 & 8 & 0,6 & \\
\hline & & & 8 & 0,6 & \\
\hline & Rata-rata & & & 0,6 & Sedang \\
\hline
\end{tabular}

Sumber: Data Primer yang diolah peneliti, 2021

Tabel di atas menunjukkan bahwa terjadi peningkatan kemampuan pemahaman konsep siswa dengan kategori tinggi sebanyak 6 orang, kategori sedang sebanyak 24 orang dan kategori rendah sebanyak 3 orang. Secara keseluruhan terjadi peningkatan kemampuan pemahaman konsep siswa rata-rata 0,6 berada pada kategori sedang. Sehingga dapat disimpulkan bahwa berdasarkan hasil tes pemahaman konsep siswa berada pada kategori cukup dan besar peningkatan pemahaman konsep siswa berada pada kategori sedang, maka media pembelajaran berbasis GeoGebra dapat meningkatkan kemampuan pemahaman konsep siswa.

Angket respon belajar siswa diberikan setelah siswa melakukan uji coba media pembelajaran. Berikut hasil analisis data angket respon belajar siswa pada saat uji coba II: 
Jurnal Penelitian Matematika dan Pendidikan Matematika

ISSN 26158132 (cetak)

ISSN 26157667 (online)

Tabel 11. Hasil Analisis Data Angket Respon Siswa

\begin{tabular}{|c|c|c|c|c|}
\hline No & Aspek Penilaian & & Rata-Rata Respon Siswa & Kriteria \\
\hline 1 & Ketertarikan Media Pembelaj & & 94,55 & Positif \\
\hline 2 & $\begin{array}{l}\text { Kepuasan Menggunakan } \\
\text { Pembelajaran }\end{array}$ & Media & 92,12 & Positif \\
\hline 3 & Bahasa, Istilah dan Materi & & 96,97 & Positif \\
\hline 4 & Kemudahan & & 93,43 & Positif \\
\hline
\end{tabular}

Sumber: Data Primer yang diolah peneliti, 2021

Secara keseluruhan respon siswa terhadap penggunaan media pembelajaran berbasis GeoGebra menunjukkan rata-rata 94,27\% dengan kriteria positif. Hal ini dapat disimpulkan bahwa siswa tertarik menggunakan media pembelajaran berbasis GeoGebra yang dikembangkan peneliti.

Berdasarkan hasil analisis data kevalidan, kepraktisan dan keefektifan penggunaan media pembelajaran berbasis GeoGebra memenuhi kriteria valid, praktis dan efektif, sehingga dapat dilakukan produksi massal dan penyebaran produk, agar dapat diuji cobakan dengan subyek penelitian yang lebih banyak maupun dijadikan bahan perbandingan dengan menggunakan media pembelajaran lainnya.

\section{Development (Tahap Pengembangan)}

Pada tahap penyebaran dilakukan pengemasan produk dan penyebarluasan media pembelajaran yang telah dikembangkan. Produk hasil pengembangan yang telah memenuhi kriteria valid, praktis dan efektif dikemas dalam bentuk CD pembelajaran beserta buku petunjuk penggunaannya. Produk hasil pengembangan diberikan kepada beberapa relasi guru matematika yang tergabung dalam MGMP matematika kota Palopo untuk dilakukan uji cobakan kepada siswanya.

Hasil penelitian pengembangan ini mempunyai persamaan dengan beberapa penelitian sebelumnya antara lain penelitiannya Novianti (2014), Ramdhani (2017), Syafitri, Mujib, Netriwati, Anwar, \& Wawan (2018) dan Kinasih (2017). Persamaan penelitian tersebut adalah mengembangkan media pembelajaran berbasis GeoGebra yang memenuhi kriteria valid, praktis dan efektif. Meski jenis penelitian dan media yang digunakan sama, terdapat perbedaan meliputi lokasi penelitian, subyek uji coba dan materi pada media pembelajaran.

Kelebihan media pembelajaran yang dihasilkan peneliti dibandingkan penelitian lainnya adalah media pembelajaran yang dikembangkan peneliti mencakup materi yang lebih luas dan lengkap yaitu tentang keliling, luas dan keterkaitan materi antara panjang sisi, keliling dan luas persegi panjang, persegi, jajar genjang, belah ketupat, layang-layang, trapesium dan segitiga. Selain itu dari segi tampilan media pembelajaran seperti website dengan tombol-tombol pilihan menu yang interaktif. Media pembelajaran yang dikembangkan peneliti dapat digunakan secara offline dan online. Sehingga dapat digunakan di dalam kelas maupun belajar mandiri di rumah secara fleksibel di mana saja dan kapan saja. Kekurangan yang merupakan keterbatasan penelitian pada pengembangan media pembelajaran matematika berbasis GeoGebra ini adalah Hasil tes dan pengerjaan angket secara online tidak bisa menjamin bahwa subyek ujicoba melakukan secara obyektif sesuai kemampuan yang sebenarnya dia miliki. Selain itu siswa yang mempunyai kemampuan rendah akan kesulitan untuk meningkatkan kemampuannya tanpa ada bimbingan dari guru. 


\section{Kesimpulan}

Berdasarkan hasil penelitian dan pembahasan, dapat disimpulkan bahwa:

1. Proses pengembangan media pembelajaran berbasis GeoGebra materi segiempat dan segitiga untuk kelas 7 SMP Datok Sulaiman Palopo dikembangkan dengan model pengembangan 4D yang terdiri dari tahapan define, design, development dan dissemination.

2. Hasil pengembangan media pembelajaran berbasis GeoGebra materi segiempat dan segitiga untuk kelas 7 SMP Datok Sulaiman Palopo telah memenuhi kriteria kevalidan, kepraktisan dan keefektifan. Hal ini ditunjukkan dengan hasil validasi ahli media 3,53 dan ahli materi 3,47 berada pada kategori tinggi dengan tingkat kevalidan valid. Hasil angket keterlaksanaan penggunaan media sebesar $89 \%$ media pembelajaran dapat dilaksanakan masuk kategori tinggi dengan tingkat kepraktisan praktis. Hasil tes penguasaan materi $81,81 \%$ siswa mencapai ketuntasan belajar dengan pemahaman konsep $71,47 \%$ berada pada kategori cukup dengan nilai gain rata-rata 0,6 dan 94,27 siswa merespon positif sehingga memenuhi kriteria efektif.

\section{DAFTAR PUSTAKA}

Agung, S., Ma'rufi, M., \& Ilyas, M. (2019). Pengembangan Perangkat Pembelajaran Berbasis Media Aplikasi Geogebra Pada Materi Geometri Untuk Meningkatkan Higher Order Thinking Skills Siswa. MaPan, 7(2), 194-210. https://doi.org/10.24252/mapan.2019v7n2a3

Asryana, A., Sanapiah, S., \& Kinasih, I. P. (2017). Pengembangan Media Pembelajaran Interaktif Menggunakan Geogebra Untuk Meningkatkan Kemampuan Spasial Siswa. Media Pendidikan Matematika, 5(2), 107. https://doi.org/10.33394/mpm.v5i2.1836

Bayu, W., Zulkifli, D., \& Syaputra, A. (2018, January). Pacu Berfikir Kreatif dan Inovatif di Era Revolusi Industri 4.0. Media Pustakawan, 8, 1-56. Retrieved from https://ristekdikti.go.id/wp-content/uploads/2018/05/Layout-Majalah-Ristekdikti-I2018-Update-Page-20180426.pdf

Hadiyanti, R. (2012). Keefektifan Pembelajaran Kooperatif Numbered Head Together Terhadap Kemampuan Pemahaman Konsep. Unnes Journal of Mathematics Education., 1(1). https://doi.org/10.15294/ujme.v1i1.262

Hidayat, F. N., \& Tamimuddin, M. (2015). Pemanfaatan Aplikasi GeoGebra untuk Pembelajaran Matematika. Jogyakarta: PPPPTK Matematika.

Hobri. (2010). Metodologi penelitian pengembangan (aplikasi pada penelitian pendidikan matematika). Jember: Pena Salsabila.

Marufi, Pasandaran, R. F., \& Yogi, A. (2018). Pemahaman konsep geometri mahasiswa berdasarkan gaya kognitif mahasiswa. Jurnal Penelitian Matematika Dan Pendidikan Matematika, 1(2), 56-67.

NCTM. (2000). Executive Summary Principles and Standards for School Mathematics Overview. Reston, Virginia: The NCTM, Inc. 
Novianti, R. (2014). Pengembangan Media Pembelajaran Berbasis Geogebra pada Materi Kubus dan Balok. Universitas Negeri Makassar.

Parta, I. N. (2009). Pengembangan Model Pembelajaran Inquiry untuk Penghalusan Pengetahuan Matematika Mahasiswa Calon Guru Melalui Pengajuan Pertanyaan. UNESA.

Prastowo, A. (2011). Panduan Kreatif Membuat Bahan Ajar inovatif. Yogyakarta: Diva Pers.

Purwanti, R. D., Pratiwi, D. D., \& Rinaldi, A. (2016). Pengaruh Pembelajaran Berbantuan GeoGebra Terhadap Pemahaman Konsep Matematis ditinjau dari Gaya Kognitif. AlJabar: Jurnal Pendidikan Matematika, 7(1), 115-122.

Ramdhani, S. (2017). Pengembangan Media Pembelajaran Konsep Luas Bidang Datar Berbasis Perangkat Lunak GeoGebra. JES-MAT, 3(2), 95-110.

Rochmad. (2012). Desain Model Pengembangan Perangkat Pembelajaran Matematika. Kreano: Jurnal Matematika Kreatif-Inovatif, 3(1), 59-72.

Sugiyono. (2012). Metode Penelitian Kuantitatif, Kualitatif dan R\&D. Bandung: Alfabeta.

Syafitri, Q., Mujib, M., Netriwati, N., Anwar, C., \& Wawan, W. (2018). The Mathematics Learning Media Uses Geogebra on the Basic Material of Linear Equations. Al-Jabar : Jurnal Pendidikan Matematika, 9(1), 9-18. https://doi.org/10.24042/ajpm.v9i1.2160

Syahbana, A. (2016). Belajar Menguasai GeoGebra (Program Aplikasi Pembelajaran Matematika). Palembang: NoerFikri Offset.

Wibawanto, W. (2017). Desain dan Pemrograman Multimedia Pembelajaran Interaktif. Jember: Penerbit Cerdas Ulet Kreatif. 